\title{
PISANG AMBON DAN AGAR-AGAR RUMPUT LAUT TERHADAP HEMOGLOBIN IBU HAMIL
}

\author{
GIVING AMBON BANANA AND SEAWEED GRASS JELLY ON PREGNANT \\ HEMOGLOBIN
}

\author{
Nancy Olii, Nurnaningsih Ali Abdul \\ Program Studi D-IV Kebidanan \\ Politeknik Kesehatan Kemenkes Gorontalo \\ Kontak Penulis: oliinancy7@gmail.com
}

\begin{abstract}
ABSTRAK
Kejadian anemia yang tertinggi di Kota Gorontalo tahun 2017 terdapat di Puskesmas Kota Selatan sebanyak 24,7\%, ibu hamil di Puskesmas Kota Selatan sudah mengkonsumsi tablet Fe, tetapi masih kurang mengetahui dan mengkonsumsi makanan yang tinggi vitamin $\mathrm{C}$ dan zat besi. Penelitian ini bertujuan untuk mengetahui pengaruh pemberian buah pisang ambon dan agar-agar rumput laut terhadap kadar Hemoglobin ibu hamil di wilayah kerja Puskesmas Kota Selatan Kota Gorontalo. Metode penelitian ini menggunakan Pre-Experiment dengan rancangan one group pretest-postest design. Sampel dalam penelitian ini berjumlah $30 \mathrm{ibu}$ hamil. Adapun hasil penelitian menunjukkan bahwa ada pengaruh pemberian buah pisang ambon dan agar-agar rumput laut terhadap kadar Hemoglobin ibu hamil di wilayah kerja Puskesmas Kota Selatan Kota Gorontalo. Terjadi peningkatan kadar Hemoglobin yang pesat setelah ibu hamil mengkonsumsi pisang ambon daripada ibu hamil yang mengkonsumsi agar-agar rumput laut.
\end{abstract}

Kata kunci: pisang ambon, agar-agar rumput laut, kadar Hemoglobin

\section{ABSTRACT}

The highest incidence of anemia in Gorontalo City in 2017 was in the City Health Center as much as 24.7\%, pregnant women at the City Health Center had consumed Fe tablets, but still did not know and consume foods high in vitamin $C$ and iron. This study aims to determine the effect of administration of ambon bananas and seaweed gelatin on Hemoglobin levels of pregnant women in the working area of South City Health Center, Gorontalo City. This research method uses Pre-Experiment with the design of one group pretest-posttest design. The sample in this study amounted to 30 pregnant women. The results of the study showed that there was an effect of giving ambon banana and seaweed gelatin on the Hemoglobin levels of pregnant women in the working area of the City Health Center in the City of Gorontalo. A rapid increase in Hemoglobin levels after pregnant women consumed Ambon banana than pregnant women who consumed seaweed gelatin.

Keywords: ambon banana, seaweed gelatin, hemoglobin levels 


\section{PENDAHULUAN}

Anemia dalam kehamilan masih merupakan masalah gizi utama di Indonesia, hal ini terbukti prevalensi pada wanita hamil sebanyak 63,5\%. Empat tahun terakhir prevalensi anemia tidak menunjukan penurunan yang cukup bermakna. (Purwandari, dkk, 2016).

Penyebab utama dari anemia pada kehamilan adalah kekurangan zat besi yang berasal dari makanan akibat minimnya kemampuan ekonomi keluarga. Anemia dalam kehamilan dapat menyebabkan gangguan pada pertumbuhan janin baik sel tubuh maupun sel otak, peningkatan frekuensi komplikasi pada kehamilan dan persalinan. Risiko kematian maternal, angka prematuritas, penurunan kecerdasan intelejensi, berat badan lahir rendah (BBLR), dan angka kematian perinatal meningkat (Uluwiyatun, 2014)

Salah satu upaya pemerintah dalam penanggulangan anemia adalah suplementasi tablet $\mathrm{Fe}$ yang dianggap cara paling efektif karena kandungan zat besinya padat dan dilengkapi dengan asam. Hasil penelitian menyebutkan bahwa untuk membantu penyerapan zat besi dalam tubuh, maka tablet Fe dikonsumsi bersamaan dengan Vitamin C. Vitamin C membantu penyerapan besi non heme dengan mengubah bentuk feri menjadi fero dimana bentuk fero lebih mudah diserap, dengan begitu membantu proses absorbsi zat besi dan menanggulangi proses penyembuhan dalam kasus anemia defesiensi besi. Pisang ambon merupakan salah satu buah yang mengandung zat besi dan vitamin C.

Selain vitamin $\mathrm{C}$, dibutuhkan juga beberapa senyawa yang diperlukan dalam sintesis Hemoglobin antara lain zat besi, protein dan vitamin B kompleks. Kandungan senyawa ini bisa ditemukan dalam Rumput laut (Eu-cheuma sp) (Uluwiyatun, dkk, 2014). Pembentukan sel darah merah berasal dari eritroblast di sumsum tulang, produksi sel darah merah memerlukan zat seperti, besi untuk metabolisme Hemoglobin, mioglobin, dan sitokrom, kemudian asam folat untuk metabolisme purin/pirimidin, vitamin B12 untuk daur ulang koenzim folat, dan vitamin C sebagai antioksidan dan untuk mengoptimalkan absorpsi besi.

Jumlah ibu hamil anemia di Provinsi Gorontalo tahun 2017 berjumlah 868 jiwa, terbagi di Kabupaten Gorontalo 151 jiwa, Kota Gorontalo 130 jiwa, Kabupaten Boalemo 507 jiwa, Kabupaten Bone Bolango 6 jiwa, Kabupaten Gorut 74 jiwa dan Kabupaten Pohuwato tidak ada. Jumlah ibu hamil di Kota Gorontalo berjumlah 4.217 jiwa sedangkan Kabupaten Gorontalo berjumlah 19.795 jiwa.

Berdasarkan data Dinas Kesehatan Kota Gorontalo tahun 2017 ibu hamil dengan anemia terbanyak terdapat pada puskesmas Kota Selatan sejumlah 32 jiwa dan Puskesmat Dumbo raya sejumlah 32 jiwa, dibandingkan Puskesmas Pilolodaa 29 jiwa, Puskesmas Dungingi 23 jiwa.

Berdasarkan masalah yang sudah diuraikan di atas, maka penting untuk dilakukan penelitian tentang "Pengaruh Buah Pisang Ambon dan Agar-agar Rumput Laut Terhadap Anemia Pada Ibu Hamil di Wilayah Kerja Puskesmas Kota Selatan Kota Gorontalo".

Pisang ambon merupakan salah satu jenis makanan yang dapat dikonsumsi karena kaya akan zat besi dan juga vitamin C. Vitamin C diperlukan dalam penyerapan zat besi, dengan demikian vitamin $\mathrm{C}$ berperan dalam pembentukan Hemoglobin, sehingga mempercepat penyembuhan anemia (Mahardika1, N dan Zuraida, R, 2016). Pisang ambon merupakan penganan yang dapat dikonsumsi pada semua umur tanpa memiliki efek samping, selain mudah didapatkan dan harga relatif murah dibanding buah lainnya. Berikut ini merupakan tabel komposisi gizi yang ada pada pisang ambon. 
Tabel 1. Komposisi Gizi yang Terkandung dalam 100g Buah Pisang Ambon

\begin{tabular}{|l|l|}
\hline \multicolumn{1}{|c|}{ Kandungan gizi } & \multicolumn{1}{c|}{ Jumlah } \\
\hline Kalori & $116 \mathrm{kal}$ \\
\hline Protein & $1.60 \mathrm{~g}$ \\
\hline Lemak & $0.20 \mathrm{~g}$ \\
\hline Karbohidrat & $25.80 \mathrm{~g}$ \\
\hline Kalsium $(\mathrm{Ca})$ & $8.00 \mathrm{mg}$ \\
\hline Fosfor $(\mathrm{P})$ & $32.00 \mathrm{mg}$ \\
\hline Zat besi $(\mathrm{Fe})$ & $0.50 \mathrm{mg}$ \\
\hline Vitamin A & $146.00 \mathrm{~S} . \mathrm{I}$ \\
\hline Vitamin $\mathrm{B} 1$ & $0.08 \mathrm{mg}$ \\
\hline Vitamin C & $72.0 \mathrm{mg}$ \\
\hline Air & $72.90 \mathrm{mg}$ \\
\hline
\end{tabular}

Selain bergizi pisang ambon sendiri juga memiliki berbagai khasiat antara lain makan pisang sebagai bagian dari diet teratur dapat mengurangi resiko kematian karena stroke sebanyak $40 \%$ ( Arjun Seth et al., 2014). Pisang tinggi kalium, yang membantu menormakan heartbeat dan mengatur keseimbagan ar tubuh. Selama periode sters yang tinggi, kadar potassium tubuh kita cenderung cepat habis makan pisang adalah cara yang sehat untuk menyeimbangkan mereka tanpa menggunakan obat. Pisang mengandung tryptophan, sebuah asam amino yang dapat diubah menjadi serotonin, yang mengarah ke perbaikan suasana hati. Pisang relative tinggi zat besi, yang membantu fungsi Hemoglobin tubuh. Kandungan zat besi yang cukup tinggi tersebut, dapat menstimulasi produksi Hemoglobin dalam darah bagi penderita anemia. Duah buah pisang sehari, sangat baik bagi penderita anemia. Pisang juga dapat menetralkan kelebihan asam lambung dan melapisi perut sehingga mampu mengurangi iritasi. (Gemilang, 2013).

Rumput laut adalah alga yang berukuran makroskopik dan dengan mudah dapat dikenali secara visual. Kelompok ini terdiri atas alga hi jau (Chlorophyta), alga merah (Rhodophyta), dan alga coklat (Phaeophyta). (Dwiyitno, 2011). Kandungan utama rumput laut segar adalah air yang mencapai 80-90 persen, sedangkan kadar protein dan lemaknya sangat kecil. Meski kadar lemaknya rendah, susunan asam lemaknya sangat penting bagi kesehatan.

Lemak rumput laut kaya akan omega-3 dan omega-6. Kedua asam lemak ini merupakan lemak yang penting bagi tubuh, terutama sebagai pembentuk membran jaringan otak, saraf, retina mata, plasma darah, dan organ reproduksi. Rumput laut mengandung vitamin B6 dan B12 yang dibutuhkan dalam sintesis Hemoglobin. Vitamin B6 dan asam amino serta glisin pada reaksi awal pembentukan heme. Vitamin B6 dan vitamin B12 diperlukan untuk sintesis globin. Selanjutnya interaksi antara heme dan globin akan meng-hasilkan Hemoglobin.

Rumput laut juga diketahui memiliki manfaat yang baik bagi kesehatan, antara lain bisa menjadi stimulan dalam proses penyembuhan kanker lewat kemampuannya meningkatkan daya tahan tubuh, penambah rasa yang bisa menggantikan garam dalam makanan ringan dan produk makanan olahan lainnya, Penelitian juga membuktikan bahwa, rumput laut jenis spiriluna juga dapat menstabilkan jurnlah sel-sel darah merah, sel-sel darah putih, dan Hemoglobin. Selain itu, rumput laut berfungsi mengurangi efek samping terhambatnya produksi sel-sel penghasil sel darah. Penelitian membuktikan bahwa rumput laut meningkatkan hematopoiesis, yakni pembentukan sel darah merah. Itu diyakini karena tingginya kandungan zat besi di dalamnya. 
Anemia dalam kehamilan didefinisikan sebagai penurunan kadar Hemoglobin kurang dari 11 gram\% selama masa kehamilan pada trimester 1 dan ke-3 dan kurang dari 10 gram\% selama masa post partum dan trimester 2. (Atik, dkk, 2016). Gejala awal biasnya tidak ada atau tidak spesifik (misalnya, kelelahan, kelemahan, pusing, dispnea ringan dengan tenaga). Gejala dan tanda lain mungkin termasuk pucat dan, jika terjadi anemia berat, akan mengalami takikardi atau bradikardi. Tubuh berada pada resiko tinggi untuk menjadi anemia selama kehamilan jika mengalami dua kehamilan yang berdekatan, hamil gemelli, morning sickness, tidak mengkonsumsi cukup zat besi, mengalami menstruasi berat sebelum kehamilan, hamil saat masih remaja, kehilangan banyak darah (misalnya, dari cedera atau selama operasi).

Pada kehamilan relative terjadi anemia karena darah ibu hamil mengalami hemodilusi (pengenceran) dengan peningkatan volume 30\% sampai $40 \%$ yang puncaknya pada kehamilan 32 sampai 34 minggu jumlah peningkatan sel darah 18 sampai 30\% dan Hemoglobin sampai sekitar $19 \%$ bila Hemoglobin ibu sebelum hamil sekitar 11\%, dengan terjadinya hemodilusi akan mengakibatkan anemia hamil fisiologis, dan $\mathrm{Hb}$ ibu akan menjadi 9,5 sampai $10 \mathrm{~g} \%$. Untuk menegakkan diagnosis anemia kehamilan dapat dilakukan dengan anamnesa. Pada anamnesa akan didapatkan keluhan cepat lelah, sering pusing, mata berkunang-kunang, dan keluhan mual muntah lebih hebat pada hamil muda. Pemeriksaan dan pengawaan $\mathrm{Hb}$ dapat dilakukan dengan menggunakan alat sahli. Hasil pemeriksaan $\mathrm{Hb}$ dengan sahli dapat digolongkan menjadi 4 yaitu $\mathrm{Hb}$ $11 \mathrm{~g} \%$ tidak anemia, $\mathrm{Hb} 9-10 \mathrm{~g} \%$ anemia ringan, $\mathrm{Hb} 7-8 \mathrm{~g} \%$ anemia sedang, $\mathrm{Hb}<7 \mathrm{~g} \%$ anemia berat. Pemeriksaan darah dilakukan minimal 2 kali selama kehamilan, yaitu pada trimester I dan trimester III. Dengan pertimbangan sebagian besar ibu hamil besar yang mengalami anemia, maka dilakukan pemeberian preparat Fe sebnayak 90 tablet pada ibu hamil dipuskesmas.

Anemia yang akan berpengaruh buruk terhadap kehamilan diantaranya, terjadi abortus, persalinan prematuritas, hambatan tumbuh kembang janin dalam rahim, mudah terjadi infeksi, ancaman dekompensasi kordis ( $\mathrm{Hb}<6 \mathrm{~g} \%)$, molahidatidosa, hiperemesis gravidarum, perdarahan anterpartum, ketuban pecah dini (KPD). Bahaya saat persalinan gangguan his (kekuatan mengejan), kala pertama dapat berlangsung lama, dan terjadi partus terlantar, kala dua berlangsung lama sehingga dapat melelahkan dan sering memerlukan tindakan operasi kebidanan, pada kala nifas terjadi subinvolusi uteri menimbulkan perdarahan post partum, memudahkan infeksi puerperium, pengeluaran asi berkurang, terjadi dekompensasi kordis mendadak setelah persalinan, anemia kala nifas, mudah terjadi infeksi mamae.

Anemia juga berbahaya pada janin, yang dapat Mengurangi kemampuan metabolism tubuh sehingga menganggu pertumbuhan dan perkembangan janin dalam rahim. Akibat anemia dapat terjadi gangguan dalam bentuk abortus, kematian intrauterine, persalinan prematuritas tinggi, berat badan lahir rendah, kelahiran dengan anemia, dapat terjadi cacat bawaan, bayi mudah dapat infeksi sampai kematian perinatal dan intelgesia rendah.

Nutrisi yang baik adalah cara terbaik untuk mencegah terhjadinya anemia jika sedang hamil. Makan makanan yang tinggi kandungan zat (seperti sayuran berdaun hijau, daging merah,) dapat membantu memastikan bahwa tubuh menjaga pasokan besi yang diperlukan untuk berfungsi dengan baik. Pastikan tubuh mendapatkan setidaknya $27 \mathrm{mg}$ zat besi setiap hari.

Penelitian ini bnertujuan untuk menganalisis pengaruh pemberian buah pisang ambon dan agar- agar rumput laut terhadap kadar haemoglobin pada ibu hamil diwilayah kerja Puskesmas Kota Selatan Kota Gorontalo. Hasil penelitian ini diharapkan dapat meningkatkan pemahaman ibu hamil tentang pentingnya mengkonsumsi pisang ambon dan agar-agar rumput laut, sehingga terhindar dari anemia. 


\section{METODE PENELITIAN}

Penelitian ini menggunakan metode penelitian PreExperiment dengan rancangan one group pretest-postest design untuk masing-masing perlakuan buah pisang ambon dan agar-agar rumput laut yang dilaksanakan pada bulan September-Oktober 2018 di wilayah kerja Puskesmas Kota Selatan Kota Gorontalo. Populasi dalam penelitian ini adalah ibu hamil trimester II dan III di wilayah Puskesmas Kota Selatan Kota Gorontalo. Cara pengambilan sampel dilakukan dengan menggunakan purposive sampling yaitu dengan memilih secara sengaja yang memenuhi kriteria inklusi. Sampel yang digunakan dalam penelitian ini adalah ibu hamil trimester II dan III yang mengalami anemia yang sesuai dengan kriteria inklusi dan eksklusi di Puskesmas Kota Selatan Kota Gorontalo sebanyak 60 responden.

Penelitian ini membandingkan pengaruh pemberian Pisang ambon lokal yang sudah matang seberat 250 gram yang diberikan selama 14 hari berturut-turut dengan Rumput laut jenis Gracilaria yang diolah menjadi agar-agar seberat 250 gram yang diberikan selama 14 hari berturut-turut pada pagi hari.

Dalam melaksanakan penelitian ini alat yang digunakan adalah alat bantu berupa lembar observasi dan alat GCU Hb Easy Touch uukur kadar $\mathrm{Hb}$ ibu hamil sebelum dan sesudah mengkonsumsi pisang ambon dan agar-agar rumput laut sesuai aturan yang ditetapkan. Hasil pengukuran dicatat di lembar observasi. Hb Set (Easy Touch $\mathrm{Hb}$ ) merupakan salah satu alat pemeriksaan $\mathrm{Hb}$ elektrik yang sangat mudah digunakan karena tidak membutuhkan keahlian khusus. Penggunaan Easy Touch Hb hanya memerlukan sedikit sampel darah sekitar 1 micro liter. Sampel darah yang telah diambil tersebut diletakkan pada strip cek Hemoglobinnya, kemudian strip ini dimasukkan pada alat cek $\mathrm{HB}$, dan 10 detik kemudian hasil pengukuran Hemoglobin dapat diketahui.

\section{HASIL PENELITIAN}

1. Adapun karakteristik umum responden pada penelitian ini sebagai berikut:

a. Umur

Distribusi responden berdasarkan umur dapat dilihat pada tabel di bawah ini, yaitu

Tabel 2. Karakteristik Responden berdasarkan Umur

\begin{tabular}{ccc}
\hline Umur & $\mathrm{F}$ & $\%$ \\
\hline Berisiko & 13 & 21,7 \\
\hline Tidak berisiko & 47 & 78,3 \\
\hline Jumlah & 60 & 100,0 \\
\hline
\end{tabular}

Tabel 2 menunjukkan bahwa responden berisiko sebesar $21,7 \%$.

b. Pendidikan

Distribusi responden berdasarkan tingkat pendidikan dapat dilihat pada tabel di bawah ini, yaitu:

Tabel 3. Karakteristik Responden berdasarkan Tingkat Pendidikan

\begin{tabular}{ccc}
\hline Tingkat Pendidikan & F & $\%$ \\
\hline Pendidikan Rendah & 10 & 16,7 \\
\hline Pendidikan Tinggi & 50 & 83,3 \\
\hline Jumlah & 60 & 100,0
\end{tabular}

Tabel 3 menunjukkan bahwa tingkat pendidikan responden yang berpendidikan rendah sebesar $16,7 \%$.

c. Pekerjaan 
Distribusi responden berdasarkan jenis pekerjaan dapat dilihat pada tabel di bawah ini, yaitu:

Tabel 4. Karakteristik Responden berdasarkan Jenis Pekerjaan

\begin{tabular}{ccc}
\hline Jenis Pekerjaan & F & $\%$ \\
\hline Bekerja & 7 & 11,6 \\
\hline Tidak Bekerja & 53 & 88,4 \\
\hline Jumlah & 60 & 100,0 \\
\hline
\end{tabular}
$88,4 \%$.

Tabel 4 menunjukkan bahwa sebagian besar responden yang tidak bekerja sebesar

d. Umur kehamilan

Distribusi responden berdasarkan umur kehamilan dapat dilihat pada tabel di bawah ini, yaitu:

Tabel 5. Karakteristik Responden berdasarkan Umur Kehamilan

\begin{tabular}{clc}
\hline Umur Kehamilan & F & $\%$ \\
\hline Trimester II & 27 & 45,0 \\
\hline Trimester III & 33 & 55,0 \\
\hline Jumlah & 60 & 100,0
\end{tabular}

Tabel 5 menunjukkan bahwa sebagian besar responden berada pada umur kehamilan Trimester III sebesar $55,0 \%$

e. Paritas

Tabel 6. Karakteristik Responden berdasarkan Paritas

\begin{tabular}{crr}
\hline Paritas & F & $\%$ \\
\hline Primipara & 22 & 36,7 \\
\hline Multipara & 35 & 58,3 \\
\hline Grande & 3 & 5,0 \\
\hline Jumlah & 60 & 100,0 \\
\hline
\end{tabular}

Tabel 6 menunjukkan bahwa responden dengan paritas grandemultipara berjumlah $5 \%$.

2. Analisis Univariat

Kadar $\mathrm{Hb}$ merupakan salah satu indikator untuk menentukan status anemia seseorang.

a. Kadar $\mathrm{Hb}$ sebelum pemberian buah pisang Ambon

Tabel 7. Distribusi frekuensi Kadar Hb Sebelum Pemberian Pisang Ambon

\begin{tabular}{ccc}
\hline Sebelum intervensi & F & $\%$ \\
\hline Anemia Ringan $(<11$ gr $\%)$ & & \\
Anemia Sedang $(<10 \mathrm{gr} \%)$ & & \\
Anemia Berat $(<9 \mathrm{gr} \%)$ & 30 & 100,0 \\
Jumlah & 30 & 100,0 \\
\hline
\end{tabular}

Tabel 7 menunjukkan bahwa responden dengan anemia sebesar $100 \%$.

b. Kadar Hb sesudah pemberian pisang Ambon

Tabel 8. Distribusi kadar Hb Sesudah Pemberian Pisang Ambon

\begin{tabular}{ccr}
\hline Sesudah intervensi & F & $\%$ \\
\hline Meningkat & 28 & 93,3 \\
Tidak meningkat & 2 & 6,7 \\
\hline Jumlah & 30 & 100,0
\end{tabular}

Tabel 8 menunjukkan bahwa responden yang tidak mengalami peningkatan $\mathrm{Hb}$ sesudah pemberian pisang ambon yaitu sebesar $6,7 \%$. 
c. Kadar $\mathrm{Hb}$ sebelum pemberian agar-agar rumput laut

Tabel 9. Distribusi Frekuensi Kadar Hb sebelum pemberian agar-agar Rumput Laut

\begin{tabular}{ccc}
\hline Sebelum intervensi & F & $\%$ \\
\hline Anemia Ringan $(<11 \mathrm{gr} \%)$ & & \\
Anemia Sedang $(<10 \mathrm{gr} \%)$ & 30 & 100,0 \\
Anemia Berat $(<9 \mathrm{gr} \%)$ & & \\
Jumlah & 30 & 100,0 \\
\hline
\end{tabular}

Tabel 9 menunjukkan bahwa responden mengalami anemia ringan sebesar $100 \%$.

d. Kadar $\mathrm{Hb}$ sesudah pemberian agar-agar rumput laut

Tabel 10. Distribusi frekuensi Kadar Hb sesudah Pemberian Agar-Agar Rumput Laut

\begin{tabular}{ccc}
\hline Sesudah intervensi & F & $\%$ \\
\hline Meningkat & 22 & 73,3 \\
Tidak meningkat & 8 & 26,7 \\
\hline Jumlah & 30 & 100,0
\end{tabular}

Tabel 10 menunjukkan bahwa responden yang tidak mengalami peningkatan kadar Hemoglobin yaitu sebesar 26,7\%.

3. Analisis bivariat

a. Pengaruh pemberian pisang Ambon terhadap kadar Hemoglobin ibu hamil

Untuk menganalisis pengaruh pemberian pisang ambon terhadap kadar Hemoglobin ibu hamil di Puskesmas Kota Selatan Kota Gorontalo menggunakan uji statistik Paired TTest.

Tabel 11. Distribusi Rerata Kadar Hb Sebelum dan Sesudah Pemberian Pisang Ambon

\begin{tabular}{lccc}
\hline Variabel & Min & Max & Rerata \pm SD $(\mathrm{gr} / \mathrm{dl})$ \\
\hline $\mathrm{Hb}$ Pre & 7,7 & 10,9 & $10,06 \pm 0,69$ \\
$\mathrm{Hb}$ Post & 9,0 & 12,7 & $11,34 \pm 0,71$ \\
$\Delta$ Perubahan & $-1,3$ & $-1,8$ & $1,28 \pm 0,58$ \\
\hline
\end{tabular}

Rerata Kadar Hemoglobin sebelum dan sesudah intervensi pemberian pisang ambon menunjukkan adanya kenaikan kadar Hemoglobin responden. Tabel 11 menunjukkan bahwa kadar Hemoglobin responden mengalami kenaikan sebesar 1,28 gr/dl setelah konsumsi pisang ambon.

Tabel 12. Korelasi Hb Sebelum dan Sesudah Konsumsi Pisang Ambon

\begin{tabular}{|c|c|c|c|c|}
\hline & & $\mathrm{N}$ & Correlation & Sig. \\
\hline Pair 1 & $\begin{array}{l}\text { Hb sebelum dan } \\
\text { sesudah konsumsi } \\
\text { pisang ambon }\end{array}$ & 30 & 0.655 & 0.001 \\
\hline
\end{tabular}

Hasil uji pada tabel 12 menunjukkan bahwa korelasi antara dua variabel sebesar 0,655. Hal ini menunjukkan adanya hubungan yang signifikan pemberian pisang ambon terhadap peningkatan $\mathrm{Hb}$ pada ibu hamil dengan kekuatan hubungan kategori kuat.

Tabel 13. Perbedaan kadar Hemoglobin sebelum dan sesudah Intervensi pisang ambon

\begin{tabular}{lcr}
\hline Variabel & Rerata $\pm \mathrm{SD}(\mathrm{gr} / \mathrm{dl})$ & $p$ value \\
$\mathrm{Hb}$ Pre & $10,06 \pm 0,69$ & \\
Hb Post & $11,34 \pm 0,71$ & 0,001 \\
$\Delta$ Perubahan & $1,28 \pm 0,58$ & \\
\hline
\end{tabular}

*Uji paired $t$-test 
Tabel 13 menunjukkan bahwa hasil analisis uji perbedaan terhadap kadar Hemoglobin sebelum dan sesudah pemberian pisang ambon menunjukkan bahwa terdapat perbedaan kadar Hemoglobin dengan nilai $p=0,00(p<0,05)$.

Tabel 14. Distribusi Rerata Kadar Hb sebelum dan sesudah intervensi agar-agar rumput laut

\begin{tabular}{lllc}
\hline Variabel & Min & Max & Rerata \pm SD \\
\hline Hb Pre & 9,7 & 10,9 & $10,44 \pm 0,41$ \\
Hb Post & 10,3 & 11,2 & $10,80 \pm 0,30$ \\
$\Delta$ Perubahan & $-0,6$ & $-0,3$ & $0,36 \pm 0,38$ \\
\hline
\end{tabular}

Rerata Hemoglobin sebelum dan sesudah intervensi pemberian agar-agar rumput laut menunjukkan adanya kenaikan kadar Hemoglobin responden. Tabel 14 menunjukkan bahwa kadar Hemoglobin responden mengalami kenaikan sebesar 0,36 gr/dl setelah pemberian agar-agar rumput laut.

Tabel 15. Korelasi Kadar $\mathrm{Hb}$ sebelum dan sesudah konsumsi agar-agar rumput laut

\begin{tabular}{lccc}
\hline & $\mathrm{N}$ & Correlation & Sig. \\
\hline $\begin{array}{l}\text { Hb sebelum agar-agar dan } \mathrm{Hb} \\
\text { sesudah agar-agar }\end{array}$ & 30 & 0.447 & 0.013 \\
\hline
\end{tabular}

Hasil uji pada tabel 15 menunjukkan bahwa korelasi antara dua variabel adalah sebesar 0,447. Hal ini menunjukkan adanya hubungan yang signifikan pemberian agar-agar rumput laut terhadap peningkatan $\mathrm{Hb}$ pada ibu hamil dengan kekuatan hubungan kategori sedang.

Tabel 16. Perbedaan kadar $\mathrm{Hb}$ sebelum dan sesudah Diberikan agar-agar rumput laut

\begin{tabular}{ccc}
\hline Variabel & Rerata $\pm \mathrm{SD}(\mathrm{gr} / \mathrm{dl})$ & $p$ value \\
\hline $\mathrm{Hb}$ Pre & $10,44 \pm 0,41$ & \\
\hline Hb Post & $10,80 \pm 0,30$ & 0,001 \\
\hline$\Delta$ Perubahan & $0,36 \pm 0,38$ & \\
\hline
\end{tabular}

*Uji paired t-test

Tabel 15 menunjukkan bahwa hasil analisis uji perbedaan terhadap kadar Hemoglobin sebelum dan sesudah diberikan agar-agar rumput laut menunjukkan bahwa terdapat perbedaan kadar Hemoglobin dengan nilai $p=0,001(p<0,05)$.

\section{PEMBAHASAN}

1. Pengaruh pemberian pisang ambon terhadap kadar Hemoglobin ibu hamil di Puskesmas Kota Selatan Kota Gorontalo

Berdasarkan hasil penelitian menunjukkan bahwa setelah dilakukan pemberian buah pisang Ambon pada ibu hamil kadar Hemoglobin mengalami peningkatan, yaitu sebanyak 93,3\% dengan rerata kadar $\mathrm{Hb}$ sebesar 11,34 gr/dl dan selisih rata-rata kenaikan sebelum dan sesudah konsumsi buah pisang ambon yaitu 1,28 gr/dl. Hasil uji statistik dengan Paired T-test didapatkan nilai $\mathrm{p}$ value $=0,000(\mathrm{p}<0,05)$ dengan demikian $\mathrm{H} 0$ ditolak dan Ha diterima artinya ada pengaruh pemberian buah pisang ambon terhadap peningkatan kadar Hemoglobin pada ibu hamil di Puskesmas Kota Selatan Kota Gorontalo.

Responden yang tidak mengalami peningkatan $\mathrm{Hb}$ sebanyak 2 responden $(6,7 \%)$. Peneliti berasumsi bahwa tidak meningkatnya kadar $\mathrm{Hb}$ dapat disebabkan karena karakteristik pada ibu hamil berdasarkan umur, pendidikan, umur kehamilan dan paritas. Kedua responden memiliki umur > 35 tahun, dan merupakan kehamilan keempat dengan usia kehamilan trimester III. Salah satu responden berpendidikan rendah.

Menurut Manuaba dalam Ariyani (2016), wanita hamil dengan umur diatas 35 tahun juga akan rentan anemia. Hal ini menyebabkan daya tahan tubuh mulai menurun dan mudah terkena 
berbagai infeksi selama kehamilan. Tingkat pendidikan ibu hamil yang rendah mempengaruhi penerimaan informasi sehingga pengetahuan tentang anemia dan faktor-faktor yang berhubungan, serta pengetahuan tentang pentingnya zat besi menjadi terbatas.

Menurut Herawati dan Sri (2010), pada kehamilan Trimester III lebih banyak menderita anemia dibanding Trimester I dan Trimester II. Hemodilusi atau pengenceran darah selama kehamilan akan mencapai maksimal 5-8 bulan, faktor hemodilusi ini dapat menyebabkan kadar Hemoglobin darah ibu menurun.

Menurut Oktaviani, dkk (2016) paritas berhubungan dengan terjadinya anemia, karena semakin sering wanita melahirkan, lebih besar risiko kehilangan darah dan berdampak pada penurunan kadar Hemoglobin. Seorang wanita yang sudah melahirkan lebih dari 2 kali, dan terjadi kehamilan lagi keadaan kesehatannya akan mulai menurun, sering mengalami kurang darah (anemia). Hal tersebut dapat meningkatkan tingginya risiko morbiditas dan mortalitas pada ibu bayi.

Penelitian ini sejalan dengan penelitian Dewi (2017) tentang Pengaruh Konsumsi Buah Pisang Ambon terhadap Anemia pada Ibu Hamil Trimester I di Wilayah Kerja Puskesmas Balowerti didapatkan hasil $\mathrm{p}$ value $=0,001(\mathrm{p}<0,005)$ yang berarti $\mathrm{H} 0$ ditolak dan $\mathrm{H} 1$ diterima maka ada Pengaruh pemberian Buah Pisang Ambon terhadap kadar Hemoglobin pada ibu hamil trimester I di wilayah kerja puskesmas Balowerti.

Peningkatan kadar $\mathrm{Hb}$ setelah mengkonsumsi pisang ambon disebabkan karena kandungan zat besi yang merangsang pertumbuhan sel darah merah terdapat pada pisang ambon. Selain itu dalam pisang ambon juga mengandung vitamin $\mathrm{C}$ yang sangat baik untuk membantu penyerapan zat besi dalam tubuh sehingga kadar $\mathrm{Hb}$ pada ibu hamil akan semakin meningkat. Mengkonsumsi pisang ambon sebanyak 250 gram perhari selama 14 hari memberikan pengaruh terhadap peningkatan kadar $\mathrm{Hb}$ ibu hamil.

2. Pengaruh pemberian agar-agar rumput laut terhadap kadar Hemoglobin ibu hamil di Puskesmas Kota Selatan Kota Gorontalo

Berdasarkan hasil penelitian menunjukkan bahwa setelah dilakukan pemberian agar-agar pada ibu hamil kadar Hemoglobin mengalami peningkatan, yaitu sebanyak 73,3\% dengan rerata kadar Hemoglobin sebesar 10,80 gr/dl dan selisih rata-rata kenaikan sebelum dan sesudah konsumsi agar-agar rumput laut yaitu 0,36 gr/dl. Hasil uji statistik dengan Paired T-test didapatkan nilai $\mathrm{p}$ value $=0,000(\mathrm{p}<0,05)$ dengan demikian $\mathrm{H} 0$ ditolak dan Ha diterima artinya ada pengaruh pemberian agar-agar rumput laut terhadap peningkatan kadar Hemoglobin pada ibu hamil di Puskesmas Kota Selatan Kota Gorontalo.

Responden yang tidak mengalami peningkatan sebanyak 8 responden (26,7\%). Peneliti berasumsi tidak terjadi peningkatan kadar Hemoglobin pada 8 responden disebabkan karena umur, usia kehamilan, dan paritas. 2 responden memiliki usia kehamilan yang pada trimester III, 2 responden dengan paritas grande multipara, dan 1 responden berumur $>35$ tahun dengan usia kehamilan trimester III, serta 2 responden berumur $<20$ tahun.

Umur $<20$ dan $>35$ tahun menurut Oktaviani dkk (2016) sebagian besar memiliki kadar Hemoglobin yang rendah. Sementara untuk paritas dikatakan tinggi, bila seorang ibu melahirkan anak $>4$. Seorang wanita yang telah melahirkan lebih dari 2 kali, lebih besar risiko kehilangan darah yang berdampak pada penurunan kadar Hemoglobin.

Usia kehamilan trimester III sangat mempengaruhi kadar Hemoglobin pada ibu hamil, hal ini sejalan dengan teori dari Irianti dkk (2014), Hemodilusi terjadi pada usia kehamilan 2832 minggu yang menyebabkan kadar Hemoglobin dalam tubuh ibu semakin menurun akibat terjadinya peningkatan volume plasma darah sementara jumlah sel-sel darah merah yang 
diproduksi hanya sedikit. Kebutuhan zat besi selama kehamilan hingga persalinan yaitu sebanyak $1240 \mathrm{mg}$, akibat terjadinya peningkatan volume plasma darah, pemenuhan kebutuhan plasenta dan janin, untuk kebutuhan ibu yang meningkat sertasebagai persiapan kehilangan darah saat persalinan.

Menurut Fanny dkk (2012) upaya lain yang dapat dilakukan, dengan memperhatikan pola konsumsi ibu hamil yang harus tetap mengacu pada pola makan sehat dan seimbang. Pengaturan makan pada ibu hamil bukan pada jumlah atau kuantitas melainkan pada kualitas atau komposisi zat-zat gizi, sebab faktor ini lebih efektif dan fungsional untuk kesehatan ibu dan janinnya. Misalnya untuk meningkatkan konsumsi bahan makanan tinggi besi seperti susu, daging, dan sayuran hijau. Kurangnya asupan nutrisi berpotensi untuk mengalami penurunan kadar $\mathrm{Hb}$, apalagi jika ibu kekurangan asupan gizi seperti asam folat, vitamin B12, vitamin $\mathrm{C}$ dan zat besi. Zat-zat tersebut yang membuat sel darah merah menjadi sehat.

Hal ini sejalan dengan penelitian dari Qudsiah dkk (2012) bahwa faktor langsung yang mempengaruhi kejadian anemia yaitu kadar Hemoglobin $<11$ gr/dl, adalah pola konsumsi tablet $\mathrm{Fe}$, perdarahan, dan penyakit infeksi. Ibu hamil yang memiliki kadar Hemoglobin <11 gr/dl harus mengkonsumsi tablet Fe guna membantu pembentukan sel-sel darah merah untuk peningkatan kadar Hemoglobin. Sementara menurut Uluwiyatun dkk (2014) Ibu hamil selain mengkonsumsi tablet besi, perlu didukung dengan pola nutrisi yang mengandung beberapa senyawa yang diperlukan dalam sintesis Hemoglobin.

Rumput laut merupakan salah satu bahan makanan yang mengandung beberapa senyawa yang diperlukan dalam sintesis Hemoglobin seperti zat besi, protein dan vitamin B kompleks. Mengkonsumsi agar-agar rumput laut dapat meningkatkan produksi sel-sel darah merah. Peningkatan kadar $\mathrm{Hb}$ ibu harus didukung dengan mengkonsumsi makanan akan zat besi itu sendiri, utamanya dari zat besi hem yang terdapat dalam hewani yang absorbsinya sampai $25 \%$, sayuran hijau sebagai sumber yang baik pula dan buah-buahan sebagai sumber vitamin $\mathrm{C}$ yang membantu penyerapan zat besi dalam tubuh.

Upaya yang dilakukan dalam meningkatkan kadar $\mathrm{Hb}$ ibu hamil untuk mengurangi kejadian anemia yaitu dengan pemberian tablet Fe diikuti dengan mengkonsumsinya secara teratur, mengatur asupan gizi ibu hamil dengan mengkonsumsi makanan yang tinggi besi seperti susu, daging, sayuran hijau dan mengkonsumsi buah-buahan yang mengandung zat besi dan Vitamin C. Berdasarkan hasil penelitian di atas, buah pisang ambon dan agar-agar rumput laut dapat meningkatkan kadar Hemoglobin, untuk itu buah dapat dikonsumsi oleh ibu hamil dan akan lebih efektif lagi jika dibarengi dengan konsumsi tablet Fe secara teratur.

Keterbatasan dalam penelitian ini yaitu peneliti tidak mengontrol asupan makanan, sehingga belum bisa menunjukkan bahwa kenaikan Hemoglobin murni disebabkan oleh pemberian buah pisang ambon dan agar-agar rumput laut, atau ada faktor lain yang tidak dapat dianalisis pada penelitian ini.

\section{KESIMPULAN}

Terdapat peningkatan kadar Hemoglobin ibu hamil setelah mengkonsumsi pisang ambon dan agar-agar rumput laut di Puskesmas Kota Selatan Kota Gorontalo. Akantetapi, mengkonsumsi pisang ambon akan lebih memberikan peningkatan kadar Hemoglobin pada ibu hamil. Hal ini kemungkinan besar karena kandungan zat besi yang berfungsi untuk pembentukan Hemoglobin dengan vitamin $\mathrm{C}$ yang bermanfaat untuk penyerapan zat besi yang terdapat pada Pisang ambon merupakan perpaduan manfaat yang menguntungkan untuk peningkatan kadar Hemoglobin pada darah. 


\section{REFERENSI}

Arjun Seth, B. ., Mossavar-Rahmani, Y., Victor Kamensky, M. ., Silver, B., M.D, Kamakshi Lakshminarayan, M. ., Wassertheil-Smoller, S. (2014). Potassium intake and risk of stroke in hypertensive and nonhypertensive women in the Women's Health Initiative. US National Library of Medicine National Institutes of Health, 45(10), 2874-2880. https://doi.org/10.1161/STROKEAHA.114.006046

Dewi, R. (2017). Pengaruh Konsumsi Buah Pisang Ambon Terhadap Anemia Pada Ibu Hamil Trimester I Di Wilayah Kerja Puskesmas Balowerti. Jurnal Ilmu Kesehatan MAKIA, Vol.4 No.1.

Dwiyitno. (2011) Rumput Laut Sebagai Sumber Serat Pangan Potensial, Squalen Vol. 6 No.1.

Gemilang, J. (2013). Khasiat Selangit Daun-Daun dan Buah-Buah Ajaib Tumpas Beragam Penyakit Berbahaya. Yogyakarta: Araska.

Kementerian Perdagangan Republik Indonesia. (2011). Rumput Laut dan Produk Turunannya. Jakarta: Warta Ekspor.

Mahardika1, N \& Zuraida, R. (2016) Vitamin C Pada Pisang Ambon (Musa Paradisiaca S.) dan Anemia Defisiensi Besi. Majority Volume 5 Nomor 4.

Manuaba, dkk. (2010). Ilmu Kebidanan, Penyakit Kandungan dan KB Untuk Pendidikan Bidan. Jakarta: EGC.

Muslikah, E. (2017). Efektifitas Pemberian Tablet Fe Dan Buah Pisang Ambon (Musa Paradisiaca Var. Sapientum (L) Kunt dengan Tablet Fe dalam Meningkatkan Kadar Hemoglobin Siswi Anemia di SMA 1 Nguter Kabupaten Sukoharjo.

Notoatmodjo, S. (2012). Metodologi Penelitian Kesehatan. Jakarta: Rineka Cipta.

Proverawati, A. (2011). Anemia dan Anemia Kehamilan. Yogyakarta: Nuha Medika.

Purwandari, A, dkk. (2016). Faktor-Faktor Yang Berhubungan Dengan Kejadian Anemia. Jurnal Ilmiah Bidan Volume 4 Nomor 1.

Uluwiyatun, dkk. (2014). Pengaruh Konsumsi Rumput Laut (Eucheuma Sp) Terhadap Peningkatan Kadar Hemoglobin dan Status Fe Ibu Hamil Anemia di Kabupaten Pekalongan. Jurnal Kebidanan Vol. 3 No. 7.

Wardhany, K. (2014). Khasiat Ajaib Pisang Khasiatnya A to Z Dari Akar Hingga Kulit Buahnya. Yogyakarta: Rapha Publishing.

Purwandari, A, dkk. (2016). Faktor-Faktor Yang Berhubungan Dengan Kejadian Anemia. Jurnal Ilmiah Bidan Volume 4 Nomor 1.

Uluwiyatun, dkk. (2014). Pengaruh Konsumsi Rumput Laut (Eucheuma Sp) Terhadap Peningkatan Kadar Hemoglobin dan Status Fe Ibu Hamil Anemia di Kabupaten Pekalongan. Jurnal Kebidanan Vol. 3 No. 7.

Wardhany, K. (2014). Khasiat Ajaib Pisang KhasiatnyaA to Z Dari Akar Hingga Kulit Buahnya. Yogyakarta: Rapha Publishing. 